For: Transactions of the Royal Historical Society, Sixth Series (26) 2016

\title{
LAST RESORT OR KEY RESOURCE? WOMEN WORKERS FROM THE NAZI-OCCUPIED SOVIET TERRITORIES, THE REICH LABOUR ADMINISTRATION AND THE GERMAN WAR EFFORT
}

\author{
Elizabeth Harvey
}

\section{READ 25 SEPTEMBER 2015}

\begin{abstract}
Foreign labour was an essential resource for the Nazi war economy: by September 1944, around six million civilian labourers from across Europe were working in the Reich. Any initial readiness on the part of the peoples of Nazioccupied Europe to volunteer for work in the Reich had quickly dissipated as the harsh and often vicious treatment of foreign workers became known. The abuse and exploitation of foreign forced labourers by the Nazi regime is well documented. Less well understood is why women formed such a substantial proportion of the labour recruited or forcibly deported from occupied eastern Europe: in September 1944, a third of Polish forced labourers and just over over half of Soviet civilian forced labourers were women. This article explores the factors influencing the demand for and the supply of female labour from the Nazi-occupied territories of the Soviet Union, particularly after the appointment of Fritz Sauckel as Plenipotentiary for Labour in March 1942. It explores the attitudes of labour officials towards these women workers and shows how Nazi gender politics and the Nazi hierarchy of race intersected in the way they were treated.
\end{abstract}

On 16 March 1943, an official in the labour administration in Nazi-occupied eastern Ukraine sent out orders to the local labour recruitment teams. In order to meet the targets of the latest crash programme to deport Soviet civilians as labourers to the Reich, each local district under military administration was with immediate effect to 'recruit' and dispatch to the Reich 500 workers per week, 'primarily women' ('in 
erster Linie Frauen'). ${ }^{1}$ Why, one might wonder, would the recruitment teams have been told to recruit 'primarily women'?

The coercive and violent recruitment of labour in occupied Ukraine was one strand in the vast history of forced labour under Nazi rule, involving not just mass deportations of prisoners of war and civilians to work in Germany and other countries under Nazi rule, but also forms of forced labour within the occupied countries themselves. ${ }^{2}$ To talk of forced labour entails definition, as Mark Spoerer and others have discussed: there were gradations of forced labour, and in wartime Nazi Germany, with its highly regulated labour regime applying also to German men and women, it would be inaccurate to talk of German workers being free of coercion. ${ }^{3}$ But for the purposes of the following discussion of foreign forced labour working in the Reich, it is helpful to refer to the criteria outlined by Spoerer that a forced labourer is unable to terminate their employment of their own accord and has little or no control over their conditions of living and working. ${ }^{4}$

On the basis of that definition, forced labour in Nazi Germany was predominantly foreign: labour was a fruit of conquest. Spoerer estimates the accumulated total of foreign workers (civilians and POWs) deployed in the Reich over the course of the Second World War at around 12 million, of whom 80-90 per cent could be regarded - according to his definition - as forced labourers. ${ }^{5}$ Statistics for September 1944 showed 5.97 million foreign civilians working in the Greater German Reich, who at that point constituted 26 per cent of the Reich's (civilian) labour force. ${ }^{6}$ Forced labour comprised not only foreign civilian deportees plus

\footnotetext{
${ }^{1}$ Wirtschaftsinspektion Mitte, Chefgruppe Arbeit (an Verteiler), betr. Anwerbung von Ostarbeitern für das Reich, 16. März 1943. Bundesarchiv [= BA] Berlin, R3901, 20273. ${ }^{2}$ Pioneering studies include: Edward Homze, Foreign Labor in Nazi Germany (Princeton, 1967); Ulrich Herbert, Fremdarbeiter: Politik und Praxis des „Ausländer-Einsatzes “ in der Kriegswirtschaft des Dritten Reiches (Berlin and Bonn, 1985); Ulrich Herbert (ed.), Europa und der ,Reichseinsatz “: Ausländische Zivilarbeiter, Kriegsgefangene und KZ-Häftlinge in Deutschland 1938-1945 (Essen, 1991).

${ }^{3}$ Mark Spoerer, Zwangsarbeit unter dem Hakenkreuz: Ausländische Zivilarbeiter, Kriegsgefangene und Häftlinge im Deutschen Reich und im besetzten Europa 1939-1945 (Stuttgart and Munich, 2001), 10-19; Mark Spoerer and Jochen Fleischhacker, 'Forced Laborers in Nazi Germany: Categories, Numbers, and Survivors', Journal of Interdisciplinary History, 33 (2002), 169-204, here 173-6; Marc Buggeln, 'Unfreie Arbeit im Nationalsozialismus: Begrifflichkeiten und Vergleichsaspekte zu den Arbeitsbedingungen im Deutschen Reich und in den besetzten Gebieten', in Marc Buggeln and Michael Wildt (eds), Arbeit im Nationalsozialismus (Munich, 2014), 231-52.

${ }^{4}$ Spoerer, Zwangsarbeit, 15.

${ }^{5}$ Ibid., 221.

${ }^{6}$ Ibid., 9, 222.
} 
prisoners of war (the latter totalling 2.19 million at the start of 1945), but also concentration camp prisoners (including foreign Jews brought to the Reich) and German Jews deployed as forced labourers: including them brings the cumulative total of forced labourers in the Reich during the war to an estimated 13.5 million. A further calculation would bring in additional estimates of forced labour undertaken within the occupied countries under Nazi rule. ${ }^{7}$ In the Reich, the atrocious treatment of workers from eastern Europe was notorious: among civilian forced labourers from the occupied Soviet territories, Spoerer suggests that around 170,000 died. ${ }^{8}$

If historical research on forced labour was relatively sparse in the 1960s and 1970s, since Ulrich Herbert's landmark study in 1985 a huge literature has developed, some studies exploring the role of regime agencies and individual companies employing forced labourers, others tracing how forced labourers were part of local economies. ${ }^{9}$ Crucially, this work has increasingly drawn on the testimonies of former forced labourers, many of whom - as Johannes-Dieter Steinert has shown - were dragged to Germany as children and adolescents. ${ }^{10}$ Most recently, studies have extended their focus to the labour administration in the occupied territories, asking both about deportations to the Reich and the ways in which people were made to 'work for Germany' in their own countries. ${ }^{11}$

The majority of foreign labourers working in the Reich were male. Women, however, constituted a rising proportion of the total foreign labour force in the course of the war, and these growing contingents were recruited above all from eastern Europe. While foreign women came from across occupied Europe, it was already

\footnotetext{
${ }^{7}$ Buggeln, ,Unfreie Arbeit', 243-51.

${ }^{8}$ Spoerer, Zwangsarbeit, 228.

${ }^{9}$ Recent collections include Karsten Linne and Florian Dierl (eds), Arbeitskräfte als Kriegsbeute: Der Fall Ost- und Südosteuropa 1939-1945 (Berlin, 2011); Andreas Heusler, Helmuth Trischler and Marc Spoerer (eds), Rüstung, Kriegswirtschaft und Zwangsarbeit im „Dritten Reich“ (Munich, 2010); Dieter Pohl and Tanja Sebta (eds), Zwangsarbeit in Hitlers Europa: Besatzung, Arbeit, Folgen (Berlin, 2013) and (with a wider comparative dimension) Kerstin von Lingen and Klaus Gestwa (eds), Zwangsarbeit als Kriegsressource in Europa und Asien (Paderborn, 2014).

${ }^{10}$ Alexander von Plato, Almut Leh and Christoph Thonfeld (eds), Hitler's Slaves: Life Stories of Forced Labourers in Nazi-Occupied Europe (New York and Oxford, 2010); JohannesDieter Steinert, Deportation und Zwangsarbeit. Polnische und sowjetische Kinder im nationalsozialistischen Deutschland und im besetzten Osteuropa 1939-1945 (Essen, 2013).

${ }^{11}$ Karsten Linne, Florian Dierl, Zoran Janjetović, Pflicht, Zwang und Gewalt: Arbeitsverwaltungen und Arbeitskräftepolitik im deutsch besetzten Polen und Serbien 19391944 (Essen, 2013); Tanja Penter, Kohle für Stalin und Hitler: Arbeiten und Leben im Donbass 1939 bis 1953 (Essen, 2010).
} 
clear in 1941, before the arrival of civilian workers from the occupied Soviet territories, that the bulk of women workers coming into Germany were from Poland and that the proportion of women among the total of Polish workers in the Reich was higher than among the contingents from other countries. ${ }^{12}$ The arrival of civilian labour recruits/deportees from the occupied Soviet territories brought a further upswing in the proportion of foreign workers who were female: already by early summer 1942 it was evident that that women were constituting around half of the transports. In September 1944, of the 5.97 million civilian foreign workers deployed in the Reich, one third were women. ${ }^{13}$ Just over half of all civilian forced labourers from the occupied Soviet territories and a third of the forced labourers from occupied Poland were female, and Polish and Soviet women conversely formed the biggest contingents among foreign female workers. Of the 1,990,367 foreign women working in the Reich in September 1944, 586,091 were from Poland and 1,112,137 were 'Ostarbeiterinnen', the term used by the National Socialist regime for the women brought as labourers to the Reich from the occupied territories of the Soviet Union. ${ }^{14}$ Such figures contrast with the lower absolute numbers and the lower proportion of women workers among the labour recruited from occupied western Europe: for instance in September 1944, 29,379 Belgian women and 42,654 French women were working in the Reich, constituting 14.6 per cent of Belgian workers and 6.6 per cent of French workers respectively. ${ }^{15}$

Gender has rarely been in the forefront of the concerns of historians writing about forced labour. ${ }^{16}$ Many studies have masked or downplayed the issue. However, references are to be found in the literature to the gender composition of the labour deportees, and one obvious starting point for thinking about patterns in the recruitment and exploitation of female forced foreign labourers is the correlation pointed out by Ulrich Herbert thirty years ago between the proportion of foreign labourers of a particular nationality that were women and the position of that

\footnotetext{
${ }^{12}$ Der Arbeitseinsatz im Deutschen Reich Nr. 21 (1941), 5.November 1941, 19.

${ }^{13}$ Der Arbeitseinsatz im Großdeutschen Reich Nr. 11/12 (1944), 30. Dezember 1944, 11.

${ }^{14}$ Herbert, Fremdarbeiter, 272.

${ }^{15}$ Ibid.; Der Arbeitseinsatz im Großdeutschen Reich Nr. 11/12 (1944), 30. Dezember 1944, 11.

${ }^{16}$ Important exceptions include Gabriella Hauch, ,Zwangsarbeiterinnen und ihre Kinder: Zum Geschlecht der Zwangsarbeit', in: Oliver Rathkolb (ed.), NS-Zwangsarbeit: Der Standort Linz der ,Reichswerke Hermann Göring AG Berlin“, 1938-1945, vol. 1 (Linz, 2001), 355-448; Tamara Frankenberger, Wir waren wie Vieh: Lebensgeschichtliche Erinnerungen ehemaliger sowjetischer Zwangsarbeiterinnen (Münster, 1997).
} 
nationality in the Nazi racial hierarchy. The lower the status in that hierarchy, the higher the proportion of women among those recruited. ${ }^{17}$ The significance of this correlation, though, demands to be explored further: how self-evident was it that the Nazi labour administration would recruit more women of a 'lower' racial category (Poles, Ukrainians, Belorussians) for work in the Reich than women from the occupied countries of western Europe?

One set of insights into the recruitment of female forced labourers from the Soviet Union derives from studies of labour mobilization policies within the Reich. These policies were shaped by assumptions about priorities in the war economy, about how far prisoners-of-war and foreign civilians should be brought in to fill gaps, and - at a time when the regime was eliminating the Jews from wartime German society - how incoming 'alien' workers were to be strictly segregated from Germans. Along with the overall dynamic of evolving policy on foreign labour there were changing perceptions of what foreign women, and particularly eastern European women, were good for. Initially, these focused largely if not exclusively on the deployment of Polish women into agricultural and domestic work, but from mid-1942 onwards the incoming 'Ostarbeiterinnen' became seen increasingly in terms of their potential to fill jobs in industry, particularly in armaments-related production. Here, historians have traced how the drive to deploy foreigners, and specifically foreign women, was linked to the difficulty of getting more German women to work in industry above and beyond those already bound, increasingly long-term, into industrial work. ${ }^{18}$ As these studies have shown, the mass influx of foreign women into semi-skilled and unskilled production-line jobs and their deployment in heavier and more hazardous work relieved some of the pressure on the labour administration to squeeze more under wartime conditions out of German women already working in industry, and to propel additional German women into industrial jobs. ${ }^{19}$ However, there is still scope for further probing of the question whether 'Ostarbeiterinnen' were seen by employers and the labour administration as a preferred resource (compared to male 'Ostarbeiter' and/or German women) or simply as a last resort. ${ }^{20}$ It is also not

\footnotetext{
${ }^{17}$ Herbert, Fremdarbeiter, 271.

${ }^{18}$ Homze, Foreign Labor, 10; Rüdiger Hachtmann, 'Industriearbeiterinnen in der deutschen Kriegswirtschaft 1936 bis 1944/45', Geschichte und Gesellschaft 19 (1993), 332-66.

${ }^{19}$ Hachtmann, 'Industriearbeiterinnen', 348, 350.

${ }^{20}$ See Herbert, Fremdarbeiter, 207 on contemporary perceptions of the work performance of 'Ostarbeiterinnen' compared to German women.
} 
clear from studies hitherto whether labour officials thought there were any limits on what even women workers deemed to be 'racially inferior' could be expected to do.

Regional studies of German occupation policy shed further light on the reason for the large numbers of women recruited for work in the Reich from the occupied Soviet territories by teasing out the 'push' factors in different regions of Ukraine and Belorussia. The conditions within which deportations took place were shaped by Soviet military conscription and evacuation measures, unemployment, food shortages, economic dislocation and population displacement following German occupation, and subsequently the spread of partisan resistance. ${ }^{21}$ German responses to these conditions and the occupiers' assumptions about the existence and scope of 'surplus' or 'unwanted' population in the occupied territories helped determine the scale and composition of the transports to Germany from early 1942 onwards. Women, particularly young women, were a prominent element in the pool of potential labour and subjected along with their fellow-countrymen to inducements, propaganda and direct coercion from the recruiting commissions combing the occupied Soviet territories from the end of 1941. Yet it is still worth asking how far the proportion of women who ended up in labour transports to the Reich was a matter of accident or design.

The 'pull' and 'push' factors at work in the recruitment of 'Ostarbeiterinnen' highlight what may appear as a straightforward logic of substitution that governed Nazi wartime efforts to keep the economy in the Reich and in the occupied territories supplied with labour. At the same time, the insights of gender historians alert us to the singular paradoxes at work in the racist Nazi 'rationality' that constructed Soviet women workers as endlessly flexible and interchangeable 'hands'. These paradoxes may help illuminate further the correlation between the imagined hierarchy of race and the recruitment of female labour. In the 1980s, Gisela Bock showed how theories based on both 'racial hygiene' and racial anthropology attenuated the polarity of the

\footnotetext{
${ }^{21}$ Christian Gerlach, Kalkulierte Morde: Die deutsche Wirtschafts- und Vernichtungspolitik in Weißrußland 1941 bis 1944 ((Hamburg, 1999), esp. 449-93; Babette Quinkert, Propaganda und Terror in Weißrussland 1941-1944: Die deutsche, geistige' Kriegführung gegen Zivilbevölkerung und Partisanen (Paderborn, 2009), 257-73; Penter, Kohle für Stalin und Hitler, 179-291; Herwig Baum, ,“Für die Stadt Kiew wird eine'Fangaktion' vorbereitet...'“: Akteure und Praxis der Zwangsarbeiterrekrutierungen in der Ukraine während des Zweiten Weltkrieges', in: Linne and Dierl (eds), Arbeitskräfte als Kriegsbeute, 270-302; Dieter Pohl, Die Herrschaft der Wehrmacht: Deutsche Militärbesatzung und einheimische Bevölkerung in der Sowjetunion 1941-1944 (Munich, 2008), 305-19.
} 
sexes in their construction of 'inferior' human types or racial groupings. ${ }^{22}$ She argued that this assumption - that 'inferior races' lacked the polarity of the sexes characteristic of the 'superior' peoples - was at work in the regime's treatment of foreign women workers. Along with Polish women, Soviet women were constructed as the 'other' of German womanhood within the wartime workforce, with Jewish women and Sinti and Roma women being regarded as lower still in the Nazi hierarchy of race. However, such constructions were bizarrely inconsistent: stereotypes of Soviet women could conjure up both the 'asexual phantasm' of an endlessly exploitable 'work hand' and fixate with racist obsessiveness on their supposed hyperfecundity. ${ }^{23}$

The attention paid by historians of gender to the question of women's bodies and their reproductive as well as productive capacity has also informed research on Nazi policies on race, sexuality and population: this in turn opens further perspectives on the deportation of Soviet (and Polish) women to work in the Reich. In one view, forced labour and mass labour deportations also served to attack the 'biopower' of eastern European peoples. ${ }^{24}$ This was a vision expressed at its racist and misogynist extreme by the SS racial expert Erhard Wetzel in his notorious commentary on 'General Plan East' (Generalplan Ost) with its fantasies of mass anti-natalist campaigns in a future occupied Russia. ${ }^{25}$ From another angle, the importation of 'Slavic' women alongside men has been interpreted as the effort to create a sexual 'buffer': their presence was, it has been suggested, part of a deliberate strategy to curb

${ }^{22}$ Gisela Bock, Zwangssterilisation im Nationalsozialismus: Studien zur Rassenpolitik und Frauenpolitik (Opladen, 1986), 135-7. On this idea of a racist ,attenuation' of sexual polarity, see also Gabriella Hauch, ,Die Institutionalisierung der NS-Bevölkerungs- und Sexualpolitik gegen Ostarbeiterinnen und Polinnen: „Modell Oberdonau“? in: Gabriella Hauch (ed.), Frauen im Reichsgau Oberdonau: Geschlechtsspezifische Bruchlinien im Nationalsozialismus (Linz, 2006), 215-26, here 216-17, and Frankenberger, Wir waren wie Vieh, 44-5.

${ }^{23}$ Hauch uses the term 'asexuelle Phantasmen': 'Institutionalisierung', 217. For examples of German stereotypes of Slavic women's alleged hyperfecundity, see Bock, Zwangssterilisation, 440-1.

${ }^{24}$ On labour and labour deportations in the context of anti-natalist measures against eastern European populations: Bock, Zwangssterilisation, 445; Homze, Foreign Labor, 29-30; Frankenberger, Wir waren wie Vieh, 20-1.

${ }^{25}$ Erhard Wetzel, Stellungnahme und Gedanken zum Generalplan Ost des Reichsführers SS, 27. April 1942, in: Czesław Madajczyk (ed.), Vom Generalplan Ost zum Generalsiedlungsplan (Munich, 1994), 50-81, here 73-5; see also Bock, Zwangssterilisation, 440-2. 
sexual contact between German women and the foreign men who were constructed as a threat to the German national body. ${ }^{26}$

Soviet women may thus have appeared to recruiters as an accessible and interchangeable mass of 'pure labour' destined for whatever menial tasks they were set and subject, like their menfolk, to uninhibited force; they may also have been sought as female labour for specific sorts of 'women's work'. Women may have figured as an 'unproductive' surplus in the occupied territories, or as a 'biological threat', to be displaced as part of population and spatial restructuring and on that basis destined for potential dispatch to the Reich, they may even have been regarded as a 'sexual buffer' protecting German women from the attentions of eastern European men. This article takes these hypotheses as a starting-point for asking how far those in charge of labour deployment and other labour officials explicitly reflected on or expressed their perceptions and motives for recruiting Soviet women for labour in the Reich. It is beyond the scope of this article to sum up the thinking on these questions on the part of all the agencies involved in the German civilian and military apparatus of occupation and the authorities concerned with the labour question within the Reich. Instead, the following discussion considers examples from official decrees, publications and internal correspondence in order to offer some pointers to the thinking of labour officials about the recruitment and deployment of women from the occupied Soviet territories in the Reich as 'Ostarbeiterinnen'.

\section{Questions of supply and demand}

In January 1941, Friedrich Syrup, a senior civil servant in in the Reich Ministry of Labour, articulated his vision of a multinational labour pool marshalled and mobilized across the expanding economic space under Nazi domination in such a way that 'reserves' would be tapped and 'surpluses' shifted to areas of demand: the imagery was of flows and streams resulting in supranational cooperation to the benefit of all. ${ }^{27}$ Syrup's expansive rhetoric masked both the measures increasingly used to stop western European workers in the Reich terminating their contracts in order to go

\footnotetext{
${ }^{26}$ For the suggestion that this was a factor in the recruitment of eastern European women for work in the Reich, see Gisela Schwarze, Kinder, die nicht zählten: Ostarbeiterinnen und ihre Kinder im Zweiten Weltkrieg (Essen, 1997), 98; Frankenberger, Wir waren wie Vieh, 24.

${ }^{27}$ Friedrich Syrup, ,Probleme des Arbeitseinsatzes im europäischen Großraum', Der Vierjahresplan Jg. 5, Nr. 1-3, Januar 1941, 20-1.
} 
home ${ }^{28}$ and the by now established practices developed by the German labour offices in Poland of coercion and violence in the recruitment of labour for the Reich. It also passed over the ways in which racial/ethnic restructuring in Poland was implicated in the creation of 'surpluses' of potential labour, and the involvement of the labour administration in these displacements and selections. ${ }^{29}$ The recruitment policy in Poland had by the autumn of 1941 brought more than a million Poles to the Reich, just over a quarter of them women, and subjected them to draconian and stigmatizing special decrees. ${ }^{30}$ The precedent for forcing civilian women alongside men onto labour transports to the Reich was thus in place when German troops invaded the Soviet Union. However, the mass deportation to the Reich of female alongside male civilian labour from the occupied territories of the Soviet Union was not an immediate imperative at the outset of occupation and emerged piecemeal in the winter of 1941/2. The rounding-up of women was part of the wider picture of the quest for any and all 'hands' and reflected perceptions of where a 'surplus' of labour existed, but it also came to include the specific targeting of women as women.

Expecting a quick victory, the regime leadership assumed in the summer of 1941 - despite predictions to the contrary from labour experts in the field as well as in the Reich - that transporting forced labourers from the newly-occupied Soviet territories to the Reich would be superfluous. ${ }^{31}$ The focus instead was on seizing agricultural produce, in the process depriving the local population to the point of famine and flight from the cities, and forcing the population to work in situ for the Germans. ${ }^{32}$ To secure and control this local labour, a network of labour offices was quickly set up both in the areas under civilian administration (Reich Commissariat Ostland and Reich Commissariat Ukraine), and in the areas nearer the front line that

\footnotetext{
${ }^{28}$ Spoerer, Zwangsarbeit, 97.

${ }^{29}$ On the involvement of the labour administration in the expulsion and displacement of Poles in the annexed territories and in the General Government, see Karsten Linne, ,Volkstumspolitik und Arbeiterrekrutierung im Reichsgau Wartheland', in: Linne and Dierl (eds), Arbeitskräfte als Kriegsbeute, 107-38, idem., ,Die deutsche Arbeitsverwaltung zwischen „Volkstumspolitik“ und Arbeiterrekrutierung - das Beispiel Warthegau”, and idem, „,Sklavenjagden“ im Arbeiterreservoir - das Beispiel Generalgouvernement”, in: Linne, Dierl and Janjetović, Pflicht, Zwang und Gewalt.

${ }^{30}$ Linne, ,Die deutsche Arbeitsverwaltung', and ,,Sklavenjagden“ im Arbeiterreservoir'; Der Arbeitseinsatz im Deutschen Reich, Nr. 21 (1941), 5. November 1941, 19; Diemut Majer, 'Fremdvölkische im Dritten Reich' (Boppard, 1981), 304-14.

${ }^{31}$ Gerlach, Kalkulierte Morde, 456-8. One exception to this was the dispatch of more than fifteen thousand agricultural workers from Lithuania and Belorussia to East Prussia in July and August 1941.

${ }^{32}$ Penter, Kohle für Stalin und Hitler, 186-7.
} 
remained under military administration. ${ }^{33}$ In a succession of decrees from August 1941 onwards, a labour obligation was imposed on both sexes: this initially covered Jews aged 14-60 and non-Jews aged 18-45: the age range for non-Jews was subsequently extended. ${ }^{34}$ With the mass murder of Soviet Jews already under way, the Nazi occupiers saw forced labour for Jews as a short-term interlude before these workers, too, would be murdered and replaced as workers by non-Jews. ${ }^{35}$ In the first phase of occupation, Jews and non-Jews, the latter including women with children and the elderly, were drafted into 'work columns' deployed on road-building, infrastructure repair, or snow clearance. ${ }^{36}$

As the Nazi assault on the Soviet Union stalled from the autumn of 1941 onwards, more and more German men had to be called up to replace the men lost on the Eastern Front, leaving ever more gaps in the war economy. ${ }^{37}$ Soviet prisoners of war were the first to be considered as a labour supply, but by the beginning of November 1941 so many POWs were already dead or dying of starvation and murderous neglect that the decision was taken, under Goering's lead as the head of the Four Year Plan apparatus, to recruit civilians. ${ }^{38}$ In December 1941, to speed up recruitment of Soviet civilian labour the Reich Labour Ministry dispatched recruitment teams (Werbekommissionen) to the occupied Soviet territories, including the former Baltic states, staffed by seconded officials from regional labour offices in the Reich. A new target of more than 600,000 recruits from the occupied Soviet territories was set on 24 February 1942: this would subsequently be raised to between 1.4 and 1.5 million after the appointment of Fritz Sauckel as Plenipotentiary for Labour (Generalbevollmächtigter für den Arbeitseinsatz or GBA) on 21 March 1942. ${ }^{39}$ As targets grew ever more dizzying, patterns of interaction between recruiters and local populations that had been seen in Poland played out once again. Initial efforts at recruitment elicited some compliance among those who believed recruiters' promises and who sought an escape from poverty, hunger and destruction in their immediate surroundings. ${ }^{40}$ However, reports quickly filtered back about the horrors of

\footnotetext{
${ }^{33}$ Baum, ,"Fangaktion“, 273-5; Penter, Kohle für Stalin und Hitler, 197, 207.

${ }^{34}$ Gerlach, Kalkulierte Morde, 452; Pohl, Herrschaft der Wehrmacht, 306.

${ }^{35}$ Gerlach, Kalkulierte Morde, 454.

${ }^{36}$ Pohl, Herrschaft der Wehrmacht, 307.

${ }^{37}$ Herbert, Fremdarbeiter, 137-43.

${ }^{38}$ Ibid., 140-3, 148-9.

${ }^{39}$ Ibid., 158; Quinkert, Propaganda und Terror, 259; Pohl, Herrschaft der Wehrmacht, 312.

${ }^{40}$ Penter, Kohle für Stalin und Hitler, 198; Gerlach, Kalkulierte Morde, 467.
} 
the journey to the Reich, about being treated like prisoners, stigmatized with the OST badge (like the Poles with their P badge), fed starvation rations with mouldy and rotten food, put up in filthy and primitive barracks, abused in the workplace and paid virtually nothing. The readiness to use force had been inherent in the process of recruitment from the start: as this news spread in the occupied territories, recruiters soon came to depend on threats and coercion. ${ }^{41}$

For all the parallels with the deportations of Polish labour, the significant proportion or even preponderance of women among the labour deportees from the occupied Soviet territories was a new departure. Observations by labour administrators based in the occupied eastern territories and those in Berlin, together with comments from the recruitment officials in the field, shed some light on the reasons for this. The recruiting commissions were already finding in early 1942 in their areas of recruitment in the occupied eastern territories a shortage of men: women were for several reasons a significant or predominant element among the civilian population of working age from teenagers upwards. First, the Soviet authorities had in face of the German invasion evacuated plant and skilled manpower eastwards, depleting the adult male workforce. ${ }^{42}$ Second, men who had been called up to the Red Army had been killed or captured: among these were the estimated 2.53 million Soviet prisoners who died in captivity, many within the occupied territories. ${ }^{43}$ Third, the Wehrmacht, Organisation Todt and the railways administration required labour on the spot in the occupied territories and were quick to snap up any skilled male workers available. ${ }^{44}$ From late 1942 , the absence of men intensified as the partisan movement gained momentum; German anti-partisan activity with the goal of seizing labour in turn escalated resistance further. ${ }^{45}$

\footnotetext{
${ }^{41}$ Quinkert, Propaganda und Terror, 258-9.

${ }^{42}$ Rolf-Dieter Müller, ed., Die deutsche Wirtschaftspolitik in den besetzten sowjetischen Gebieten 1941-3 (Boppard, 1991), 5. Penter, Kohle für Stalin und Hitler, 189, stresses for the Donbass region the evacuation of plant but warns against overestimating the extent of the evacuation of industrial workers.

${ }^{43}$ On the deaths of Soviet prisoners on the territory of occupied Belorussia, see Gerlach, Kalkulierte Morde, 788-859; on the estimated total deaths of Soviet POWs, 857; on the fate of Soviet POWs in the Donbass region of Ukraine, see Penter, Kohle für Stalin und Hitler, 202-7.

${ }^{44}$ Pohl, Herrschaft der Wehrmacht, 308.

${ }^{45}$ Ibid., 316; Baum, „Fangaktion“, 302; for the atrocities involved in the seizure of labour deportees in the course of , anti-partisan' operations in Belorussia, see Gerlach, Kalkulierte Morde, 996-1007.
} 
From the outset, recruitment teams struggled to meet demands set by the Reich labour authorities. To take the example of the head of one such team operating in southern Ukraine in 1941/2, one can observe both his rapid resort to intimidation and violence to fill the 'transports', and the unfolding of his bureaucratic rationale that made a virtue out of necessity. This entailed 'selling' the idea of female recruits to the labour administration back home. Having arrived in Uman in southern Ukraine shortly before Christmas 1941 with the mission (as he understood it) to recruit labour for his home region of Bavaria, Graf Kajetan von Spreti reported in February 1942 that he had dispatched his first trainload of Ukrainian civilian workers for Bavaria only after having had the town governor of Uman hang two Jewish women and one Jewish man for allegedly spreading rumours about the fate of workers sent to Germany and causing panic among the deportees' parents. ${ }^{46}$ Meanwhile Spreti was grappling with the absence of male civilians to recruit, having established on his arrival that along with 6000 Soviet POWs present in his area of operations there were 4408 civilian workers registered with the local labour office (Arbeitsamt) of whom the overwhelming majority (4100) were female. Among the women registered he identified female agricultural workers, including milkmaids, that farms in Bavaria urgently required. Having sought confirmation from the Reich Labour Ministry in Berlin $^{47}$ and received the go-ahead from the Reichskommissariat Ukraine for the recuitment of female labour, particularly for agriculture, ${ }^{48}$ he then sought in the following months to square his 'transports' not just with a series of upward revisions of the total target but also with a stream of contradictory orders from Bavaria:

First of all it was only men to be sent, because it had not yet been clarified how women were to be deployed (...) then I received a telephone message from the Bavarian regional labour office on 20 February 1942 that suddenly 2000 female workers were needed as soon as possible. I received a further

\footnotetext{
${ }^{46}$ Reichskommission Uman an den RAM z.Hd Min. Rat Lesch [sic], Berlin, betr. Einsatz von Sowjetrussen, Berichterstatter Graf Spreti, 16. Feb. 1942. Staatsarchiv [= StA] München, Arbeitsämter Freising, 762. On Spreti's recruitment operations, see also Elsbeth Bösl, Nicole Kramer and Stephanie Linsinger, Die vielen Gesichter der Zwangsarbeit. „Ausländereinsatz “ im Landkreis München 1939-1945 (Munich, 2004), 40-1.

${ }^{47}$ Graf Spreti, Uman, an den Reichsarbeitsminister betr. Einsatz sowjetrussischer Kriegsgefangener, 24. Dez. 1941. StA München, Arbeitsämter Freising, 762.

${ }^{48}$ Der Reichskommissar für die Ukraine, i.v.v. Wedelstaedt, Landeshauptmann, an Reichskommissar beim Gebietskommissar / Arbeitseinsatz, Uman, 28. Dez. 1941. StA München, Arbeitsämter Freising, 762.
} 
message on 23 February ordering the dispatch of 5000 workers for the spring planting, predominantly female. Then I received the order that transports from 18 April onwards were to comprise only women. This was then corrected on 26 April to the effect that it was now also possible to deploy male agricultural workers. It will be evident that this sort of management makes the task here much more difficult. ${ }^{49}$

Spreti's correspondence with the Bavarian regional labour office also made it clear how young the recruits were: of the 900 that had by March 1942 been set to work in Bavaria, most were aged between 16 and 20, had not previously been employed and had been taken out of schools or institutions. ${ }^{50}$

In the subsequent months it became a routine assumption among labour officials that the transports of civilian deportees from the occupied eastern territories would include substantial numbers of mainly young women: indeed, propaganda designed to combat increasingly well-informed antipathy towards the prospect of working in Germany came to address young women specifically. ${ }^{51}$ Meanwhile, Sauckel had in his first programmatic announcement on 20 April 1942 not only signalled his overall plans for 'a gigantic new deployment' of workers of both sexes from the age of 15, but also an eye-catching programme specifically to recruit Soviet women to work in Germany. Described as a special mission from Hitler, Sauckel announced his goal of recruiting ‘ 400,000 - 500,000 strong and healthy girls’ from the occupied eastern territories to work as servants in urban and rural households in Germany. ${ }^{52}$ This announcement was coupled with a reassurance to those German women who had not yet been drawn into the workforce that, on Hitler's orders, the supreme importance of the health of German women and mothers took precedence over any plans for conscripting women for work in war production. ${ }^{53}$

\footnotetext{
${ }^{49}$ Werbekommission Uman, Reg. Rat. Graf Spreti, Kiew, an den GBA, Berlin, betr. Erfahrungsbericht der Werbekommission Uman, 10. Juli 1942. StA München, Arbeitsämter Freising, 762.

${ }^{50}$ Präsident Landesarbeitsamt Bayern an den Reichsarbeitsminister betr. Einsatz von russischen Zivilarbeitern, 21. März 1942. StA München, Arbeitsämter Freising, 762.

${ }^{51}$ Quinkert, Propaganda und Terror, 263-4.

${ }^{52}$ Der Beauftragte für den Vierjahresplan/GBA, Das Programm des Arbeitseinsatzes, 20. April 1942. StA München, Arbeitsämter Freising, 757.

${ }^{53}$ Ibid.
} 
By late 1942, with the trawls for deportees increasingly scouring an already emptied reservoir, female labour was still presented as a relatively promising target for combing out and delivering to the Reich. ${ }^{54}$ That said, it was soon evident, for instance, that Sauckel's push to recruit hundreds of thousands of domestic servants was unrealistic: it was reported from Belorussia in January 1943 that against a target of 30,000 domestic servants, by November 1942 only a few hundred had been secured. ${ }^{55}$ By the spring of 1943, regulations regarding recruitment from the occupied Soviet territories were changed again, allowing whole families to be brought to Germany as long as half the persons in the family were aged 10 or over, and on the other hand putting in place measures to seize entire cohorts of a particular age. ${ }^{56}$

Meanwhile, the notion that the forced deportation of young women was a particular outrage was proving to be a rich seam for Soviet counter-propaganda. ${ }^{57}$ This did not go unnoticed, and in March 1943 a complaint from the German army leadership reached the labour authorities claiming that the deportation and exploitation of young Russian women in the Reich and the dismal spectacle of returnees from Germany (including pregnant women and mothers with newborns transported in unheated wagons without food) was a propaganda disaster for the German authorities in the occupied East. ${ }^{58}$ This elicited the following observation from Walter Letsch, a civil servant from the Reich Labour Ministry now seconded to Sauckel's Plenipotentiary of Labour apparatus: 'The mass recruitment and deployment of young Russian women and girls in the Reich', he noted, 'is necessary for reasons that are decisive for the outcome of the war. It is indispensable.' Moreover, he commented, 'eastern workers' were no longer for the time being being brought back home from the Reich, and pregnant women were not going to be brought back in future at all. To that extent, the 'difficulties' alluded to would not

\footnotetext{
${ }^{54}$ Chef des Wirtschaftsstabs Ost an den Inspekteur der Wi in Kaukausus, Don/Donez, Mitte, Nord betr. Arbeitseinsatz, hier: Anwerbung von russischen Arbeitskräften für das Reich, 19. Okt. 1942. BA Berlin, R3901, 20270.

${ }^{55}$ Auszugsweise Abschrift aus 'Meldungen aus den besetzten Ostgebieten', Nr. 38, Arbeitereinsatzlage, 22. Jan. 1943. BA Berlin, R3901, 20271.

${ }^{56}$ Fernschreiben an Graf Spreti von Beauftragt. GBA, RKU Rowno, 3. April 1943; Aktennotiz Graf Spreti 8. April 1943. StA München, Arbeitsämter Freising, 757.

${ }^{57}$ Quinkert, Propaganda und Terror, 264.

${ }^{58} \mathrm{OKH}$ betr. Angaben sowjetischer Agenten und Kriegsgefangener zur politischen Lage in den besetzten russ. Gebieten, 6. März 1943. BA Berlin, 20273.
} 
recur and therefore, he concluded, 'no action is necessary'(' $z u$ veranlassen ist daher nichts'). ${ }^{59}$

\section{An endlessly flexible resource?}

Farm work was one key destination for female forced labourers from Poland in the early stages of the war and initially for 'Ostarbeiterinnen' as well. With a long-term shortage of labour in agriculture caused by rural-urban migration now made more acute by the wartime conscription of farm labourers and farmers themselves, the trope of the 'overburdened German farmer's wife' was coupled with larger alarmist messages about the whole future of German 'blood' and 'soil'. ${ }^{60}$ While such arguments were used to push German youngsters into harvest help and forms of 'service' on the land, after the defeat of Poland the channelling of Polish workers who as migrant seasonal workers were long established as a source of agricultural labour on eastern German estates - on to farms in the Greater German Reich appeared to offer a less piecemeal answer. ${ }^{61}$ Polish women sent to work in the Reich between 1939 and 1941 had been predominantly placed on farms, and when Soviet women started arriving in early 1942, they too were initially directed primarily into agriculture. A study of agricultural employment in wartime Lower Austria ('Gau Oberdonau') shows the numbers of 'Ostarbeiterinnen' employed after 1942 as agricultural workers in 'Gau Oberdonau' as being on a par with male 'Eastern workers' and by May 1944 coming to equal the number of Polish women employed in agriculture there. ${ }^{62}$ Farm work, it seems, corresponded to sexist and racist assumptions on the part of the labour administration about the place of female 'Slavs' at the bottom of the wartime labour hierarchy, but also their supposed fitness and willingness to take on long hours and hard, dirty work. ${ }^{63}$ At the same time, the labour administration also saw female workers from eastern Europe as a particularly

\footnotetext{
${ }^{59}$ GBA, Vermerk Dr. Letsch betr. Angaben sowjetischer Agenten und Kriegsgefangener zur politischen Lage in den besetzten russ. Gebieten, 10. Mai 1943. BA Berlin, R3901, 20273. ${ }^{60}$ Daniela Münkel, Nationalsozialistische Agrarpolitik und Bauernalltag (Frankfurt am Main, 1996), 392-403, 439-51; Ela Hornung, Ernst Langthaler and Sabine Schweitzer, Zwangsarbeit in der Landwirtschaft in Niederösterreich und dem nördlichen Burgenland (Munich, 2004), 107-14.

${ }^{61}$ Herbert, Fremdarbeiter, 67-88.

${ }^{62}$ Hornung et al., Zwangsarbeit, 126-7.

${ }^{63}$ Ibid., 121-2.
} 
manoeuvrable mass: labour offices were more prone to switching them than their male compatriots from jobs in industry into short-time harvest work such as sugarbeet and potato harvesting. ${ }^{64}$

After 1942, the initial concentration of foreign labour in agriculture gave way to a broader deployment across economic sectors: Soviet workers, both male and female, were increasingly channelled into industrial jobs. The capacity of 'Ostarbeiterinnen' for work in industry was commented on by German observers and labour experts from a variety of perspectives. Some saw the deployment of women in Soviet industry as a factor that could now benefit the German war economy. The German Labour Front (Deutsche Arbeitsfront or DAF) issued a report in May 1943 praising women workers from the occupied Soviet territories for their levels of education and intellectual adaptability. Comparing them with German women workers, the DAF declared that 'the Ostarbeiterin shows a certain dexterity and capacity to adapt to factory work here', and noted that it was 'not uncommon' for women in the Soviet Union to learn a 'masculine' manual trade that equipped them with a basic technical training. ${ }^{65}$ Sauckel himself had cruder notions, which could be read as a colonialist and racist view of robust but primitive natives, of why

'Ostarbeiterinnen' should be set to work in German industry. These stemmed not least from Sauckel's obsession with the physical condition of the women he observed on his May 1942 visit to occupied Ukraine: in the words of his report, 'Wherever one goes one is struck by the rude health (strotzende Gesundheit) of the women.' 66 This fixed idea underlay Sauckel's blustering insistence on the dichotomy between the 'valuable' but allegedly more fragile German woman worker and the endurance of the female 'eastern worker'. The 'health' of 'Russian women' that rendered them a potential substitute for male labour again featured in his speech at a meeting of labour administrators in Weimar in January 1943: 'As long as I can get them from you I will put Russian women to work at machines. (...) Everything that lives over there in Soviet Russia is healthy. I will put these Russian women to work in their hundreds

\footnotetext{
${ }^{64}$ Ibid., 129.

${ }^{65}$ Arbeitswissenschaftliches Institut der Deutschen Arbeitsfront (ed.), Arbeitseinsatz der Ostarbeiter in Deutschland. Vorläufiger Bericht zur Untersuchung des Arbeitswissenschaftlichen Instituts über Arbeitseignung und Leistungsfähigkeit der Ostarbeiter, Berlin, Mai 1943.

${ }^{66}$ Bericht des Gauleiters Sauckel über seine Reise in die Sowjet-Ukraine in seiner Eigenschaft als Generalbevollmächtigter für den Arbeitseinsatz [Mai 1942]. BA Berlin, R43 II, 652.
} 
and thousands. They will work for us. They can hold out for 10 hours and can do every sort of man's work. ${ }^{67}$

The deployment of 'Ostarbeiterinnen' in industry in the Reich over the last three years of the war ranged from work as semi-skilled operatives to heavy unskilled labour. In the chain of substitutions and reorganizations taking place as skilled men were called up, Soviet women were both replacing men and substituting for women: however, they tended to be compared to German women. A study undertaken by Krupp comparing the work performance of Germans and foreigners of different nationality showed 'Ostarbeiterinnen' performing strikingly well against the comparator group of German women workers. ${ }^{68}$ Many employers spotted this and in the light of such experiences specifically demanded more 'Ostarbeiterinnen', particularly where they could be slotted into re-organized and standardized production processes requiring semi-skilled rather than skilled workers. ${ }^{69}$ German and Austrian women were a much less elastic reserve of labour: foreign women were both cheaper and more flexibly deployable. ${ }^{70}$ The protective legislation in force for German and Austrian women workers concerning working hours, which had been initially loosened at the very start of the war, but then restored, did not apply to foreign women workers. ${ }^{71}$ Where foreign women workers were put onto semi-skilled and unskilled production-line jobs, some limited scope opened up for employers to devise part-time shifts for German women. These were seen as an incentive, particularly after the decree of 27 January 1943 compelling hitherto non-employed German women aged 17-45 to register for war work, for German women to take up and remain in industrial work and as a way of combating absenteeism. ${ }^{72}$ Alternatively, production was re-organized so as to give 'Ostarbeiterinnen' heavier and more

\footnotetext{
${ }^{67}$ Totaler Arbeitseinsatz für den Krieg. Mobilisierung der europäischen Leistungsreserven. Programmatische Rede des Generalbevollmächtigten für den Arbeitseinsatz, Gauleiter und Reichsstatthalter Fritz Sauckel auf der ersten Tagung der Arbeitseinsatzstäbe am 6. Januar 1943 in Weimar, cited in Renate Meyer-Braun, ,Die haben uns angestarrt wie im Zoo' Frauarbeit auf Bremer Großwerften. Vortrag, Universität Bremen, 6 February 2002 (manuscript).

${ }^{68}$ Herbert, Fremdarbeiter, 207.

${ }^{69}$ Ibid., 278-81.

${ }^{70}$ Tim Kirk, Nazism and the Working Class in Austria (Cambridge, 1996), 81-4.

${ }^{71}$ Dörte Winkler, Frauenarbeit im ,Dritten Reich' (Hamburg, 1977), 90-91; 154-6.

${ }^{72}$ On the decree of 27 January 1943, see Winkler, Frauenarbeit, 134-41. Women with two children under 14 or one child below school age were exempted from the compulsion to register.
} 
hazardous work, with German women shifted to lighter tasks. ${ }^{73}$ In this way, German women workers were given an improved position in the hierarchy of the wartime workforce, with new categories defined by race and nationality extending the hierarchy downwards below them. ${ }^{74}$

The labour administration was engaged in many respects in a 'race to the bottom' in the way it sought to turn foreign female labour into 'pure' labour, boundlessly deployable. The new Maternity Protection Law of May 1942 and the 'housework day' introduced by the Labour Ministry in October 1943 were attempts to manage, rationalise and reconcile the multiple roles of German working women as mothers, in the household and in production. ${ }^{75}$ These measures were simultaneously designed to differentiate the female workforce further along lines of 'race' and nationality. Foreign women were excluded from such measures: they were denied family life and deprived of basic elements of privacy. Their bodies were exposed to scrutiny and inspection from the moment of deportation to repeated inspections in their barracks accommodation. ${ }^{76}$ They were exposed to sexual exploitation and could be punished for sex with Germans, even where evidence suggested this was coerced. ${ }^{77}$ With regard to control over reproduction, eastern European women were systematically disadvantaged compared to other foreigners. Reversing the original policy of re-deporting pregnant workers from the Reich back to their homelands, a change that took place at the end of 1942, Sauckel's labour apparatus left a loophole allowing 'western' women workers to continue to travel back to their country of origin, while this was ruled out for Polish women and 'Ostarbeiterinnen' ${ }^{78}$ In a

\footnotetext{
${ }^{73}$ Dietrich Eichholtz, Geschichte der deutschen Kriegswirtschaft 1939-1945, vol. 3: 19431945 (Berlin, 1996), 281.

${ }^{74}$ Tilla Siegel, 'Die doppelte Rationalisierung des “Ausländereinsatzes” bei Siemens', Internationale Wissenschaftliche Korrespondenz der Arbeiterbewegung [= IWK] vol. 27 (1991), no. 1, 12-24.

${ }^{75}$ On the Maternity Protection Law, see Carola Sachse, Siemens, der Nationalsozialismus und die moderne Familie: Eine Untersuchung zur sozialen Rationalisierung in Deutschland im 20. Jahrhundert (Hamburg, 1990), 47-53; on the introduction of the 'housework day', see Carola Sachse, Der Hausarbeitstag: Gerechtigkeit und Gleichberechtigung in Ost und West 1939-1994 (Göttingen, 2002), 35-47.

${ }^{76}$ Bernhild Vogel, ,Kollektive Resignation und individuelle Revolte - „Kinderlose“ Mütter in den Zwangsarbeitslagern', in: Christl Wickert (ed.), Frauen gegen die Diktatur: Widerstand und Verfolgung im nationalsozialistischen Deutschland (Berlin, 1995), 172-81;

Frankenberger, Wir waren wie Vieh, 26-27; Hauch, ,Zwangsarbeiterinnen und ihre Kinder', 369-70.

${ }^{77}$ Frankenberger, Wir waren wie Vieh, 49.

${ }^{78}$ Der Beauftragte für den Vierjahresplan/Der GBA, Merkblatt über gesundheitliche Maßnahmen bei Ostarbeitern, 30. Dez. 1942. StA München, Arbeitsämter Freising, 757.
} 
mercilessly antinatalist reversal of the enhanced 'maternity protection' granted to German women workers, abortions for 'Ostarbeiterinnen' and for Poles were decriminalized: this led in practice to forced abortions. ${ }^{79}$ If the women concerned did go ahead and give birth, they were often compelled to leave their children in crèches and 'homes' in which many died from neglect and malnutrition; meanwhile, the mothers were to return to work as soon as possible, with the concession - at least on paper - that they might be put on 'other work' such as clearing-up tasks before returning to their earlier jobs. ${ }^{80}$

There are indications that employers and labour officials alike adapted readily on the whole to a regime of exploiting eastern European women workers, in the process rolling back gender-based rules and safety precautions. Sent as a supply of labour to the Fürstlich-Plessische Bergwerke in Upper Silesia at the beginning of January 1943, Ukrainian women were hired out to building subcontractors involved in constructing new mine buildings ${ }^{81}$ while others worked alongside German women in tasks above ground. Here, the Upper Silesian mine authorities sent in March 1943 instructions to the management of individual coal mines in the region with regard to the campaign to involve more women in working in the Upper Silesian coalfields. The circular specified that coal mines must apply strict rules to the deployment of women and assign them only to jobs they were genuinely capable of. Such jobs were absolutely to exclude work at the pit bank (Hängebank). However, the instructions continued, 'insofar as foreign women are available, they can be assigned to the more difficult jobs'. ${ }^{82}$ At the same time, underlining the way in which female labour was regarded as conveniently flexible, mine managers used 'eastern women' ('Ostfrauen')

\footnotetext{
${ }^{79}$ Gabriele Czarnowski, ,Vom ,reichen Material...einer wissenschaftlichen Arbeitsstätte': Zum Problem missbräuchlicher medizinischer Praktiken an der Grazer UniversitätsFrauenklinik in der Zeit des Nationalsozialismus', in Wolfgang Freidl and Werner Sauer (eds), NS-Wissenschaft als Vernichtungsinstrument. Rassenhygiene, Zwangssterilisation, Menschenversuche und NS-Euthanasie in der Steiermark (Vienna, 2004), 225-73, esp. 23952; Hauch, ,Zwangsarbeiterinnen und ihre Kinder', 422-4.

${ }^{80}$ Vogel, ,Kollektive Resignation'.

${ }^{81}$ Fürstengrube Kattowitz, Rundschreiben Nr. 15 betr. Ostarbeitereinsatz, 16. Feb. 1943. BA Berlin, R9363, 6.

${ }^{82}$ Claassen, Geschäftsführung, Bezirksgruppe Steinkohlenbergbau Oberschlesien der Wirtschaftsgruppe Bergbau, an die Hauptverwaltungen der Steinkohlengruben, betr. Verstärkter Fraueneinsatz im oberschlesischen Steinkohlenbergbau, 10. März 1943. BA Berlin, R9363, 2.
} 
as a handy source of domestic help in their private households, deploying them out of hours cleaning windows or cleaning up after the decorator. ${ }^{83}$

Not all firms reacted the same way to being supplied with female workers. Some companies complained at being sent women when they had requested foreign men, and requested them to be swapped. Rebutting such complaints, the labour administration noted that there was nothing to be done about the high proportion of women and youngsters under 18 among the 'Ostarbeiter' transports: there was no prospect of swapping contingents of 'eastern workers' on the basis of age or physical capacity and it was up to the firms to reorganize production to ensure an 'optimal deployment' of the workers they had been sent. ${ }^{84}$ When an aircraft factory complained that the 'Ostarbeiterinnen' it had been sent were not strong enough for the work, a scribbled exchange on the correspondence between the labour officials included the comment that 'The labour office in Saxony has no men to send, and anyway, the female Ostarbeiter are stronger than the men'. ${ }^{85}$

Some taboos about deploying foreign women did remain in force. Whereas Ukrainian women constituted 28.5 per cent of the workforce in the coal mines of the Donbass in German-occupied Ukraine in July 1943, working underground as well as in jobs on the surface, all women were banned from working underground in coal mines in the Reich itself. ${ }^{86}$ This ban, declared a representative of the DAF, was based on the conviction that women could not be contemplated undertaking the 'singularly masculine' job of miners at the coalface even during wartime: this ban on working below ground applied to foreign women workers as well. ${ }^{87}$ In this case at least, the gender of the foreign women workers was regarded as decisive. Issues about the permeability or impermeability of boundaries demarcating men's and women's work

\footnotetext{
${ }^{83}$ Kassenabzugsbeleg, Fürstlich Bergwerks-AG Sekretariat, 22. März 1943. BA Berlin, R9363, 6.

${ }^{84}$ GBA, MR Dr. Letsch, MR Dr. Petzold betr. Arbeitseinsatz von Ostarbeitern in Deutschland, an das Reichsministerium für Volksaufklärung und Propaganda, 8. Okt. 1942. BA Berlin, R3901, 20270.

${ }^{85}$ GBA an den Präsidenten des Landesarbeitsamtes Sachsen, Dresden, 10. Sept. 1942. BA Berlin, R3901, 20269.

${ }^{86}$ Penter, Kohle für Stalin und Hitler, 216-17; Hans-Christoph Seidel, ,Ein buntes Völkergemisch hat eine Wanderung durch unsere Gruben gemacht': Ausländereinsatz und Zwangsarbeit im Ruhrbergbau 1940-1945', in: Klaus Tenfelde and Hans-Christoph Seidel (eds), Zwangsarbeit im Bergwerk: Der Arbeitseinsatz im Kohlenbergbau des Deutschen Reiches und der besetzten Gebieten im Ersten und Zweiten Weltkrieg, vol. 1, 75-159, here 87. ${ }^{87}$ Ernst Stein, ,Schaffende Frauen in Bergwerksbetrieben', Der Vierjahresplan 5 (1941), no. 16, November 1941, 859-61.
} 
where foreign women workers were concerned also arose in shipbuilding. In the Bremen shipbuilding yards, as Renate Meyer-Braun has shown, German women, mostly female relatives of the male employees, had taken on jobs in production from the start of the war. However, it was the deployment of 'Ostarbeiterinnen' as welders that opened up the question of the taboo about women working on board the ships under construction. For the local labour office and the factory inspections officer, with the prospect of eastern European women welders working alongside men in the conditions on board ship that were particularly hard to oversee, the gender of the 'Ostarbeiterinnen' suddenly appeared relevant: the women came into view as women not as workers requiring protection but as a potential moral threat, an 'immoral' presence in a hard-to-supervise work situation. ${ }^{88}$

In a further instance, this time in munitions production, questions of health and safety were brought into play in a discussion involving the deployment of 'Ostarbeiterinnen'. In an argument in 1942 between the regional labour office in Pomerania and the Air Ministry it was argued that 'Ostarbeiterinnen' should replace German women producing grenades in a munitions plant: the German women, it was proposed, should be 'released' due to the dangerous gases to which they were exposed. The labour officials involved in the dispute took the view that 'Ostarbeiterinnen' with their supposedly more robust constitutions should indeed be employed rather than German women. However, rather strikingly, perhaps in a residue of earlier assumptions, the deputy director of the Pomeranian regional labour office made the point that the plant should invest in better ventilation, "since after all even Ostarbeiterinnen should as far as possible be guaranteed some measure of health protection'. ${ }^{89}$

\section{'Ostarbeiterinnen' as domestic helps}

On the face of it, Sauckel's 1942 campaign to recruit young Ukrainian women to work as servants in German households flew in the face of administrative and

\footnotetext{
${ }^{88}$ Renate Meyer-Braun, 'Die haben uns angestarrt wie im Zoo' - Frauenarbeit auf Bremer Grosswerften, Bremen (Vortragsmanuskript) 2002.

${ }^{89}$ Präsident des Landesarbeitsamtes Pommern an den GBA, betr. Einsatz ausländischer Arbeitskräfte in der Lufthauptmunitionsanstalt Speck, 13. August 1942; Dr. jur. W. Holtz, Direktor, Ständ. Stellv. des Präsidenten des Landesarbeitsamtes Pommern, an Präs. Professor Jung, 18. August 1942. BA Berlin, R3901, 20270.
} 
economic logic. Leading civil servants in the Reich Labour Ministry projected an image of the labour administration across the territories under Nazi rule as dedicated to optimizing production for the war effort. ${ }^{90}$ Its purpose was to make the supply of labour from across Europe flow correctly, guided by objective analyses of shortfalls and the possibilities of substitution; it was characterized by a technocratic logic of initiative, improvization, flexibility and problem-solving. ${ }^{91}$ This logic of transparency and 'flow' was in tension with the fixed idea on the part of Hitler and Sauckel that the resources of the German household and the German housewife must be preserved and enhanced even in the midst of a wartime labour crisis. Sauckel's announcement in April 1942 that up to half a million domestic helps were to be brought from the occupied Soviet territories to relieve the burden on German housewives was a spectacular manifestation of this thinking. In the view of Edward Homze, '[a]t at time when Germany was fighting most of the world and German industry was desperately short of labor, Hitler was, in the best tradition of Viennese courtliness, worrying about the additional burden the war had placed on the German Hausfrau' ${ }^{92}$ For Ulrich Herbert, there was more than a whiff of colonialism about a policy that conjured up a notion of German privilege and comfort resting on the labour of conquered peoples. ${ }^{93}$ Yet the pledge to provide domestic help en masse was also bound up with the maintenance of conventional gender roles and ideas of the traditional 'home': the gender polarity supposedly inherent to German identity and distinguishing it from 'lower' peoples was part of the 'normality' that was to be upheld and disseminated in the face of a mass influx of foreigners into the Reich. This at least is one reading of Sauckel's April 1942 programme, where the announcement about 'hauswirtschaftliche Ostarbeiterinnen' as part of his 'gigantic' new deployment of labour from the conquered Soviet territories was coupled, as we have seen - along with fulsome praise for the efforts of German women already in the labour force with the pledge to stave off the conscription of women who were not yet employed. ${ }^{94}$

\footnotetext{
${ }^{90}$ Syrup, ,Probleme des Arbeitseinsatzes'; Walther Stothfang, , Totaler Krieg - totaler Arbeitseinsatz', Der Vierjahresplan 7 (1943) Nr. 3, 15. März 1943, 98-9.

${ }^{91}$ Walther Stothfang, ,Bilanz des Arbeitseinsatzes', Der Vierjahresplan, 7 (1943), Nr 10 (Oktober 1943), 355.

${ }^{92}$ Homze, Foreign Labor, 141.

${ }^{93}$ Herbert, Fremdarbeiter, 177.

${ }^{94}$ Der Beauftragte für den Vierjahresplan/GBA, Das Programm des Arbeitseinsatzes, 20. April 1942. StA München, Arbeitsämter Freising, 757.
} 
Allowing labour resources to vanish into the realm of private consumption thus had a political if not economic logic. Recruiting foreign servants no doubt also made sense to German middle-class housewives, given that ever fewer German girls and women wanted to accept the low wages and long hours of domestic service when other jobs beckoned. ${ }^{95}$ A perception of the 'Ostarbeiterin' as a 'natural' servant also took root within the armed forces stationed in the occupied eastern territories. ${ }^{96}$ Army units secured local women to work in their canteens, and officers started to recruit women for their own households as well, bringing them back to Germany when they went on home leave. In September 1942, once the Wehrmacht's conquest of a further swathe of Soviet territories gave Sauckel access to new supplies of labour, a meeting was held to confirm that the recruitment of domestic servants would now begin in earnest. It was noted at that meeting that the 'self-service' actions by members of the Wehrmacht were to be confirmed and legalized retrospectively. ${ }^{97}$ By November 1942, however, the practice was seemingly getting out of hand and a ban was imposed on such 'private' recruitment. ${ }^{98}$

Nevertheless, there was a countervailing logic as well. Given the rules and regulations regarding the surveillance and physical segregation of Polish and Soviet workers, their stigmatization through the $\mathrm{P}$ and OST badges and the insistence on maintaining social and sexual boundaries between them and Germans, placing Soviet women as domestic servants into German homes was problematic, all the more so given Nazi views of the German home reproducing Germanness through the intimacy of domestic life. ${ }^{99}$ One answer, signalled in the decree that implemented the

\footnotetext{
${ }^{95}$ Ingrid Wittmann, “"Echte Weiblichkeit ist ein Dienen“: Die Hausgehilfin in der Weimarer Republik und im Nationalsozialismus, in: Frauengruppe Faschismusforschung (ed.), Mutterkreuz und Arbeitsbuch. Zur Geschichte der Frauen in der Weimarer Republik und im Nationalsozialismus (Frankfurt am Main, 1977), 15-48; Mareike Witkowski, ,In untergeordneter Stellung: Hausgehilfinnen im Nationalsozialismus', in: Nicole Kramer and Armin Nolzen (eds), Ungleichheiten im „Dritten Reich“: Semantiken, Praktiken, Erfahrungen (Göttingen, 2012), 155-75.

${ }^{96}$ On soldiers' typical view of Soviet women simply as kitchen helps in their units, see: ,Die Stellung der Frau in Sowjet-Russland', Bericht der Propagandaabteilung des Luftflottenkommandos 4 vom Dezember 1943. BA Berlin, R6, 191.

${ }^{97}$ Aktenvermerk über eine Sitzung beim GBA über den Abtransport von 400000 - 500000 ukrainischer Frauen nach Deutschland für hauswirtschaftliche Arbeiten, 4. September 1942, in: Wehrmachtsverbrechen: Dokumente aus sowjetischen Archiven (Cologne, 1997), 208. ${ }^{98}$ Hauch, ,Zwangsarbeiterinnen und ihre Kinder', 370.

${ }^{99}$ On domestic ideology and German national identity, see Nancy Reagin, Sweeping the German Nation: Domesticity and National Identity in Germany, 1870-1945 (New York, 2006).
} 
recruitment campaign, was to play down the problem of racial difference by selecting candidates who would 'resemble Germans as closely as possible'. ${ }^{100}$ This peculiar strand of thinking seemingly went back to Sauckel's idiosyncratic impressions of Ukraine picked up during his May 1942 visit, when he spotted among the population 'numerous racially good, healthy and even Nordic looking people, particularly among the women'. ${ }^{101}$ In theory, domestic helps were to be selected and 'racially screened' before dispatch to Germany, but oral testimonies suggest that private employers simply picked out their candidates from a line-up of recently recruited young Soviet women at the local labour office, leaving the rest to be assigned to other jobs. ${ }^{102}$

The other approach used by the labour administration to square the circle of bringing an alien 'Ostarbeiterin' into the heart of the German home was the attempt to lay down regulations for how private homes employing such domestic helps were to be organised. ${ }^{103}$ Regulations specified that an 'Ostarbeiterin' working as a domestic servant could not share her quarters with a German servant. ${ }^{104}$ She was to carry out domestic tasks without being in close contact with the family or becoming involved in the care and education of children. ${ }^{105}$ Her employers, meanwhile, were advised to educate their servant 'in German order and housekeeping' and to refrain from discussing 'war-related difficulties and worries' in front of her. ${ }^{106}$ These elaborate instructions represented a bureaucratic operation on the part of the labour administration to preserve a sense of proper racial order and hierarchy. At the same time, they embodied a striking paradox in the way they sought to counter the very privacy and individuality that was the essence of domestic ideology and seemed

\footnotetext{
100 8. Sept 1942, Sonderaktion des GBA zur Hereinholung von Ostarbeiterinnen zugunsten kinderreicher städtischer und ländlicher Haushaltungen, Reichsarbeitsblatt Teil I, 1942, Nr $27,411$.

${ }^{101}$ Bericht des Gauleiters Sauckel. BA Berlin, R43 II, 652.

${ }^{102}$ Susanne Kraatz (ed.), Verschleppt und vergessen: Schicksale jugendlicher “OstarbeiterInnen' von der Krim im Zweiten Weltkrieg und danach (Heidelberg, 1995), 89; see also Annekatrein Mendel, Zwangsarbeit im Kinderzimmer. ,Ostarbeiterinnen' in deutschen Familien von 1939 bis 1945. Gespräche mit Polinnen und Deutschen (Frankfurt am Main, 1994).

${ }^{103}$ Merkblatt für Hausfrauen über die Beschäftigung hauswirtschaftlicher Ostarbeiterinnen in städtischen und ländlichen Haushaltungen, Reichsarbeitsblatt Teil I, 1942, Nr. 27, 413-15, ${ }^{104}$ Ibid., 414.

105 8. Sept. 1942, Sonderaktion des GBA zur Hereinholung von Ostarbeiterinnen zugunsten kinderreicher städtischer und ländlicher Haushaltungen, Reichsarbeitsblatt Teil I, 1942, Nr. $27,412$.

${ }^{106}$ Merkblatt für Hausfrauen über die Beschäftigung hauswirtschaftlicher Ostarbeiterinnen in städtischen und ländlichen Haushaltungen, 413.
} 
symbolically to drag the home into the realm of the regulated economy and the official gaze.

The first transport of domestic helps from Ukraine departed from Stalino (Donetzk) in September 1942. ${ }^{107}$ Households seeking an 'Ostarbeiterin' as a domestic servant had to apply to their local labour office and have their political reliability checked by a Party functionary. ${ }^{108}$ Those whose applications were approved were summoned to select 'their' domestic servant at the local labour office. ${ }^{109}$ From then on, employers seem to have regarded themselves as in a position to treat their servants as they pleased. At any rate, a security service (SD) report in January 1943 suggested both the satisfaction of housewives at having a servant whom they could order around at will, and their lack of regard for regulations about separation and social distance. Beyond recommending that Nazi women's organizations should be dispatched to inspect and admonish the wayward housewives, however, the report suggested little by way of remedial action: the reach of the regime in this case was inevitably limited. ${ }^{110}$

\section{Conclusion}

'In labour deployment there is no such thing as impossible', declared Fritz Sauckel in a typically grand verbal gesture made at the end of October 1942 in a circular to officials of the labour administration in the Reich and in the occupied territories. ${ }^{111}$ It corresponded to the self-image of the senior officials in the labour administration that their efforts, constituting a many-faceted 'kaleidoscope' 112 of initiatives and devices to achieve their targets, should be seen in terms of technocratic solutions to gigantic tasks and challenges. For all the euphemistic visions of balancing forces within a "new European order', the movement of labour across the continent under Nazi control was

${ }^{107}$ Generalmajor Hans Nagel, Abschlussbericht des Wirtschaftsstabes Ost, in: Müller (ed.), Die deutsche Wirtschaftspolitik, 322.

${ }^{108}$ Sonderaktion des GBA zur Hereinholung von Ostarbeiterinnen, Reichsarbeitsblatt, Teil I, 1942, Nr. 27, 410-12.

${ }^{109}$ Mendel, Zwangsarbeit im Kinderzimmer, 165.

${ }^{110}$ Meldungen aus dem Reich Nr. 349, 11. Januar 1943. See also Herbert, Fremdarbeiter, 176; Witkowski, ,In untergeordneter Stellung', 169.

${ }^{111}$ Beauftragter für den Vierjahresplan an alle Beamten und Angestellten der Arbeitseinsatzund Treuhänderbehörden im Grossdeutschen Reich, in allen angegliederten und besetzten Gebieten und im befreundeten Ausland, 30. Okt. 1942. StA München, Arbeitsämter Freising, 757.

${ }^{112}$ Stothfang, 'Totaler Krieg', 98. 
anything but a smooth flow of surpluses shifted to areas of shortage, but involved coercion on a grand scale by officials in the field and the snatching up of 'pools' created by ethno-racial displacement, enforced food shortages and flight/evacuation as front lines shifted. If Soviet propaganda chose to focus particularly on the fate of young women dragged to Germany and subjected to abuse, the bureaucratic response was to hold the line. If the forcible recruitment of young women from the occupied Soviet territories was not primarily motivated by an anti-natalist vision of decimating the Slavic peoples through attacking their reproductive potential, the actions taken by the labour administration to secure at any price the labour of women who became pregnant, including forced abortions, could make it effectively part of such a strategy.

Coming back to the quotation and the question posed at the start, the instruction to recruit 'primarily women' can be seen partly as a simple reflection of the availability of women and absence of men in occupied Ukraine and Belorussia. It does not, despite some accounts, seem to be the case that transports from the occupied eastern territories were carefully put together to ensure a 'parity of the sexes'. Any sense of labour contingents being straightforwardly 'ordered' with a pre-set composition regarding skill, age or gender is belied by the shortages on the ground and the hostility to recruitment that soon set in. It seems, rather - taking the example of Graf Spreti in the Ukraine - that recruiters in the field had scope for pushing their own recruitment solutions upon their 'home' areas.

Up to a point - for instance in the case of the campaign to secure domestic servants - women in the occupied Soviet territories were recruited specifically as women for 'female' tasks. However, they were also recruited as a generic supply to fill gaps in the labour force regardless of gender. If employers requested skilled male labour and there was none available, the labour administrators sought to manage expectations but also promoted Soviet women as a substitute. Tamara Frankenberger has suggested that the 'Ostarbeiterin' was in many respects the embodiment of an ideal worker: cheap, flexible, compliant, not subject to restrictive protective regulations and without family ties. Within the logic of 'flow' and repeated substitutions and relocations in the latter years of the war, they could appear as a supply of 'pure' labour deployable anywhere. The awkward fact of their pregnancies, which emerged as an issue already in the summer of 1942, merely prompted swift and often brutal intervention. In some cases, their previous experience and training within the Soviet economy gave them an additional advantage; more generally, their gender 
and the supposedly natural affinity with menial and dirty work made it appear that they could be summoned to undertake - for instance - cleaning or clearing-up work after hours. From the point of view of employers, who had welcomed the Nazi destruction of trade unions and restored what was characterized as managers' right to manage, the advent of such a labour supply might seem like a welcome return to a much earlier era. There remains, however, more to be done to assess the exact limits of what work the labour administration and employers deemed acceptable for 'Ostarbeiterinnen' to do and where remaining inhibitions or taboos, at least relating to work within the Reich, still prevailed.

Finally, the deployment of 'Ostarbeiterinnen' needs to be seen in relation to Nazi gender ideology, wartime policies towards German women, and the maintenance of racial hierarchies and gender polarities within and outside the workplace. The extension downwards of the labour hierarchy to create new groups at the bottom (Poles, Soviet workers, Jews) in effect enhanced the position of German women workers who would otherwise have been on the lowest rung in terms of pay and status. The availability of workers to take on the hardest jobs potentially modified the working hours and conditions of German women. This can be seen as a rationalizing strategy to induce women to juggle housework and paid work on the basis of muchvaunted protective policies and the de-privileging of others. Meanwhile, the pledge (largely unfulfilled in practice) that hard-pressed housewives and mothers of large families could acquire an 'Ostarbeiterin' as a servant was rooted in a notion of gender polarity and traditional family structures as a distinguishing marker and privilege of Germans as the ruling class of Europe. It also suggested the maintenance of a sense of 'normality' in the domestic sphere at a time when for many the comforts and routines of home were undermined by wartime conditions. The uninhibited grab for 'alien' women as servants again partly suggests a throwback to an earlier age when households could treat servants entirely as they pleased - but also a sense that these women were a novel resource absorbing the strains on Germans in wartime, part of the perks of empire brought into the German home. 